\title{
Synthesis of some Fused Heterocyclic Compounds from $\alpha$-Bromo Tetralone and Indanone
}

\author{
Ahlam M.N. Yahya \\ Department of Chemistry \\ College of Science \\ Mosul University
}

\author{
Akram N. Mohammad \\ Department of Chemistry \\ College of Education for Girls \\ Mosul University
}

(Received 31/3/2010; Accepted $13 / 7 / 2010$ )

\begin{abstract}
A number of heterocyclic compounds (7-14) were prepared by the reaction of $\alpha$ bromo ketones $(3,4)$ with 2-amino-5-phenyl-1,3,4(thiadiazole or oxadiazole) and 5-phenyl1,3,4-triazole-2-thiol. Moreover, on heating under reflux of $\alpha$-bromo ketones $(3,4)$ in the presence of ethanol with thiazole derivatives $(5,6)$ (was prepared from the reaction of $\alpha$ bromo ketone $(3,4)$ with thiourea), compounds $(7,8)$ were obtained. The structure of the synthesized compounds have been elucidated by their physical and spectral methods .
\end{abstract}

Keywords: oxadiazole, thiadiazole, triazole, tetralone, indanone, imidazole derivatives, $\alpha$-halo ketone

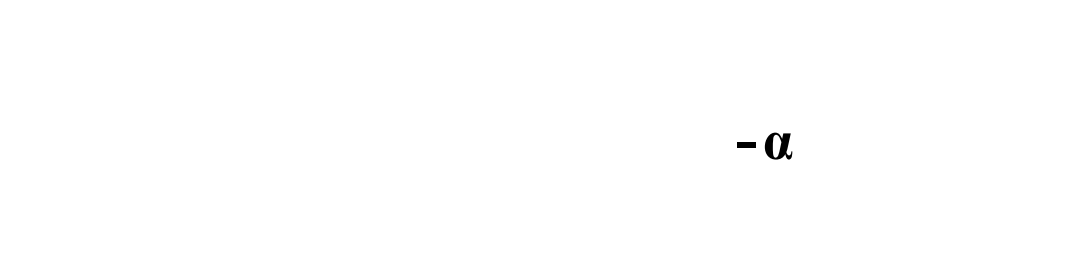

قم تحضير عدد من المركببت الملتحمة غير المتجلنسة (7 -14) من تفاعل الفا - بروموكيتون (4,3)

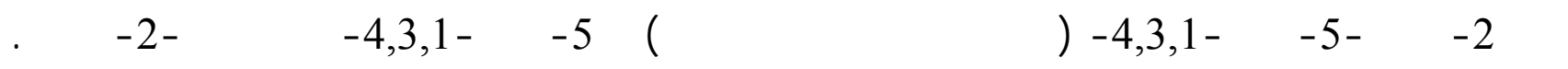

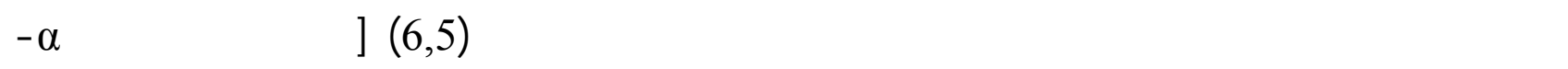

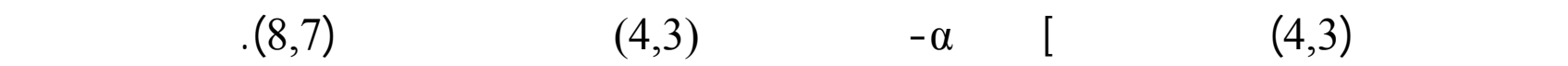

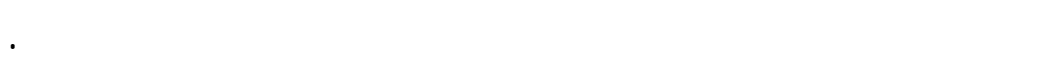

الكاملت الفتالحية: اوكسادايازول، ثايادليازول، ترايازول، مشقلت التيترالون، الاندالنو، الايميدازول، الفا هالوكيتون . 


\section{INTRODUCTION}

Tetralones and indanones are compounds which are very important as intermediate products for synthesizing various medicinal starting materials such as steroids (House et al., 1960; Brown et al.,1981), serotonin pre-synaptic inhibitor compounds with antidepressant activity (Johnson and Doub, 1999), non-steroidal anti-infllamatory $\left(\mathrm{NSAID}_{\mathrm{s}}\right)$ drugs (Brunel et al., 1995) and for the treatment of Alzheimer's disease (Sayena et al., 2003). Substituted imidazoles have been extensively used in medicine and agriculture (Barger and Dale, 1910; Dale and Laidlaw,1910). These compounds show antifungal activity (Dubini et al., 1992; petersen et al., 1993; Rolth and Fenner, 1994; Werbrouks and Debergh, 1996; Wurbrouck et al., 1996; Furtado and Minami, 1997; Urbanik et al., 1998), anticonvulsant properties (Nardi et al.,1981; Graziani et al., 1983; Robertson et al.,1986; Catto et al.,1989; Hetzheim et al., 1990; Roth and Fenner,1994); tumor-inhibiting (Keppler et al.,1987); inhibitors of p38 mitogen activated protein kinase (Liverton et al.,1999; Magnus et al., 2006), antiinflammatory (Labanauskas et al., 2006). Therefor, many investigators reported the synthesis of this type of compounds (Magnus et al., 2006; Jasinski et al., 2006; Davood et al., 2007; Shieh and Mckenna, 2008). A series of derivatives of 1,3,4-oxadiazol has been prepared and were known to have a wide spectrum of biological activity (Yarvenko et al.,1993; Piatnitski chekler et al., 2008; Levins and Wan, 2008). On the other hand, 1,3,4thiazole derivatives were synthesized and investigated their antimicrobial activity (Gong and Yang ,2006; Demirbas et al., 2008; Hadizadch and Vosooghi, 2008). Therefor, an attempt was made to prepare versatile fused heterocyclic compounds from tetralone and indanone owing to their practical significance.

\section{EXPERIMENTAL}

Melting points (M.P.) were measured on Electrothermal 9300 melting point apparatus and are uncorrected. Infrared (FT-IR) spectra were recorded on infrared spectrophotometer model tensor 27 Bruker Co., using KBr discs. Ultraviolet (UV) spectra were measured on Shimadzu UV-1650 PC ,UV-Visible spectrophotometer. 2-Amino-5-phenyl-1,3,4thiadiazole (a), 5-phenyl-1,3,4-triazole-2-thiol (b) and 2-amino-5-phenyl-1,3,4-oxadiazole (c) were prepared using a previously reported method; (Al-Juboory, 2001; Eissa, 2006; Husain and Jamal, 1987).

\section{Synthesis of $\alpha$-bromo ketones $(3,4)$ : (Kolsch , 1950; Rutherrford, 1955; House etal, 1960)}

To a solution of ( 0.3 mole, $40 \mathrm{gm})$ of 1-tetralone (1) or 1-indanone (2) in (40 ml) of ether, cooled to $\left(0^{\circ} \mathrm{C}\right)$ with $(0.3$ mole, $48 \mathrm{gm})$ of bromine was added. The mixture was heated for fifteen minutes on a water-bath to expel most of the hydrogen bromide, then cooled and filtered. The solid product was washed with ether. The melting point and spectral data were shown in (Table 1).

\section{Synthesis of 2-Amino[1,2-d]tetralino or indano-1,3-thiazole (5,6): (Koelsch , 1950; King and Hlavacek, 1950; Arcus and Barrett , 1958)}

To a solution of $(0.2$ mole, $1.07 \mathrm{gm})$ of thiourea in ethanol $(5 \mathrm{ml})$ heated under reflux, 2bromo-1-tetralone or indanone $(3,4)(0.1$ mole, $3 \mathrm{gm})$ in ethanol $(15 \mathrm{ml})$ was added during $(1.5 \mathrm{hrs})$, heating was continued for $(15 \mathrm{~min}$.). This crude reaction mixture was cooled and 
extracted with ether to remove unreacted ketone. The residue was then disolved in boiling water and filtered off. The solution was then cooled and made basic with ammonium hydroxide. The precipitate was filtered off and recrystallized from ethanol-water. The melting point and spectral data were shown in (Table 1).

Synthesis of imidazole tetrahydro thiazole derivatives $(7,8):$ (Arcus and Barrett, 1958)

A mixture of $\alpha$-bromo ketone $(3,4)(0.01$ mole $)$ and compound (5) $(0.01$ mole, 2.26 $\mathrm{gm})$ in $(40 \mathrm{ml})$ ethanol was refluxed for $(4 \mathrm{hrs}$.). The solution was then cooled and made basic with ammonium hydroxide and extracted with ether. After evaporation of ether, the precipitate was filtered off and recrystallized from ethanol-water. The physical constant and spectral data were illustrated in (Table 1).

Synthesis of fused 1,3,4-thiadiazole derivatives $(9,10)$ : (King and Hlavacek, 1950)

To a solution of $\alpha$-bromo ketone $(3,4)(0.01 \mathrm{~mole})$ in ethanol $(40 \mathrm{ml})$, 2-amino-5phenyl-1,3,4-thiadiazole (a) $(0.01 \mathrm{~mole}, 1.77 \mathrm{gm})$ was added. The reaction mixture was boiled for (3-4 hrs.).The precipitate was filtered off and recrystallized from ethanol. The physical constants and spectral data were illustrated in (Table 1).

\section{Synthesis of fused 1,3,4-triazole derivatives $(11,12)$ : ( Wiley et. al, 1951)}

To a solution of $\alpha$-bromo ketone $(3,4)(0.01 \mathrm{~mole})$ in $(40 \mathrm{ml})$ of ethanol, $(0.01 \mathrm{~mole}$, $1.77 \mathrm{gm}$ ) of 2-amino-5-phenyl-1,3,4-triazole (b) was added. The mixture was refluxed for (3 hrs.). After cooling, cold water was added to the product mixture. The precipitated product was filterd off and recrystallized from ethanol. The physical constants and spectral data were illustrated in (Table 1).

\section{Synthesis of fused 1,3,4-oxadiazole derivatives $(13,14)$ : (Wiley et. al, 1951)}

A mixture of $\alpha$-bromo ketone $(3,4)(0.01$ mole $)$ and $(0.01 \mathrm{~mole}, 1.77 \mathrm{gm})$ of 2 -amino5-phenyl-1,3,4-oxadiazole (c) in $(40 \mathrm{ml})$ of ethanol was refluxed for $(4 \mathrm{hrs}$.). The reaction mixture was cooled to room temperature then poured in ice-water $(10 \mathrm{ml})$. The precipitated product was removed by filtration, washed with ice-water and ether then recrystallized from ethanol. The physical constants and spectral data were illustrated in (Table 1). 
Table 1: Physical and spectral data for compounds (3-14).

\begin{tabular}{|c|c|c|c|c|c|c|c|c|c|c|c|c|}
\hline \multirow{2}{*}{$\begin{array}{c}\text { Comp. } \\
\text { No. }\end{array}$} & \multirow{2}{*}{$\begin{array}{l}\text { M.P } \\
\left({ }^{\circ} \mathrm{C}\right)\end{array}$} & \multirow{2}{*}{$\begin{array}{c}\text { Yield } \\
\text { (\%) }\end{array}$} & \multirow[b]{2}{*}{ Colour } & \multirow{2}{*}{$\begin{array}{c}\text { UV } \\
\text { (EtOH) } \\
\lambda_{\max } \\
(\mathbf{n m})\end{array}$} & \multicolumn{8}{|c|}{ I.R $(\mathrm{KBr}) v\left(\mathrm{~cm}^{-1}\right)$} \\
\hline & & & & & C-S & $\mathrm{C}-\mathrm{N}$ & $\mathrm{C}-\mathrm{O}$ & $\mathbf{C}=\mathbf{O}$ & $\mathrm{C}=\mathrm{C}$ & $\mathbf{C}=\mathbf{N}$ & $\mathbf{N}-\mathbf{N}$ & N-H \\
\hline 3 & $37-38^{*}$ & 55 & white & 256,300 & - & - & - & 1718 & 1600 & - & - & - \\
\hline 4 & $37-39^{*}$ & 50 & white & 254,293 & - & - & - & 1780 & 1604 & - & - & - \\
\hline 5 & $135-137^{*}$ & 50 & Yellow & 246,320 & 622 & 1348 & - & - & 1561 & 1629 & - & 3240 \\
\hline 6 & $209-211^{*}$ & 80 & $\begin{array}{c}\text { Fait } \\
\text { Brown }\end{array}$ & 246,306 & 660 & 1346 & - & - & 1608 & 1630 & - & 3262 \\
\hline 7 & $223-225$ & 45 & Brown & 252,316 & 646 & 1348 & - & - & 1561 & 1630 & - & - \\
\hline 8 & $167-169$ & 35 & Brown & 280,336 & 648 & 1388 & - & - & 1623 & 1687 & - & - \\
\hline 9 & $198-200$ & 35 & Yellow & 238,314 & 575 & 1376 & - & - & 1631 & 1690 & 1034 & - \\
\hline 10 & $130-132$ & 42 & Yellow & 248,300 & 647 & 1336 & - & - & 1604 & 1630 & 1030 & - \\
\hline 11 & $158-160$ & 40 & Yellow & 242,308 & 683 & 1351 & - & - & 1577 & 1630 & 1061 & - \\
\hline 12 & $116-118$ & 28 & Yellow & 250,302 & 649 & 1387 & - & - & 1623 & 1686 & 1029 & - \\
\hline 13 & $199-203$ & 30 & $\begin{array}{c}\text { Fait } \\
\text { yellow }\end{array}$ & 246,304 & - & 1386 & $\begin{array}{cl}\text { asym. } & 1247 ; \\
\text { sym. } & 1172\end{array}$ & - & 1596 & 1582 & 1084 & - \\
\hline 14 & $120-122$ & 55 & Yellow & 248,316 & - & 1347 & $\begin{array}{cl}\text { asym. } & 1213 ; \\
\text { sym. } & 1118\end{array}$ & - & 1616 & 1661 & 1070 & - \\
\hline
\end{tabular}

* Reported melting points ( ${ }^{\circ} \mathrm{C}$ ) for compounds 3 and 4 were (37-38) and ( 37-38.5) respectively, (Rutherford and Stevens, 1955 ); and for compound 5 and 6 was (133-134) and (213-214) respectively, (King and Halavacek, 1950)

\section{RESULTS AND DISCUSSION}

$\alpha$ - Tetralones and indanones are known for being particularly useful as synthesis intermediates for preparing different pharmaceutical starting materials (Repinskaya et al., 1982).

The Hantzsch's synthesis of thiazole (Wiley and Behr, 1951) involving reaction of the tautomeric form (II) (isothioamide) of thiourea with ( $>\mathrm{C}-\mathrm{Br}$ ) carbon of the $\alpha$-halo ketone to form 2-amino thiazole derivatives (scheme 1). The first step of the reaction of $\alpha$-bromo tetralone (3) with thiourea involves formation of a carbon-sulfur link with elimination of hydrogen bromide molecule. In the second step, ring closure takes place with eliminated of water molecule to form 2-amino[1,2-d] tetralino or indano-1,3-tetrahydro thiazole $(5,6)$ (King and hlavacek, 1950). The reaction mechanism could be illustrated as follow(scheme 1) (Wiley and Behr, 1951). 


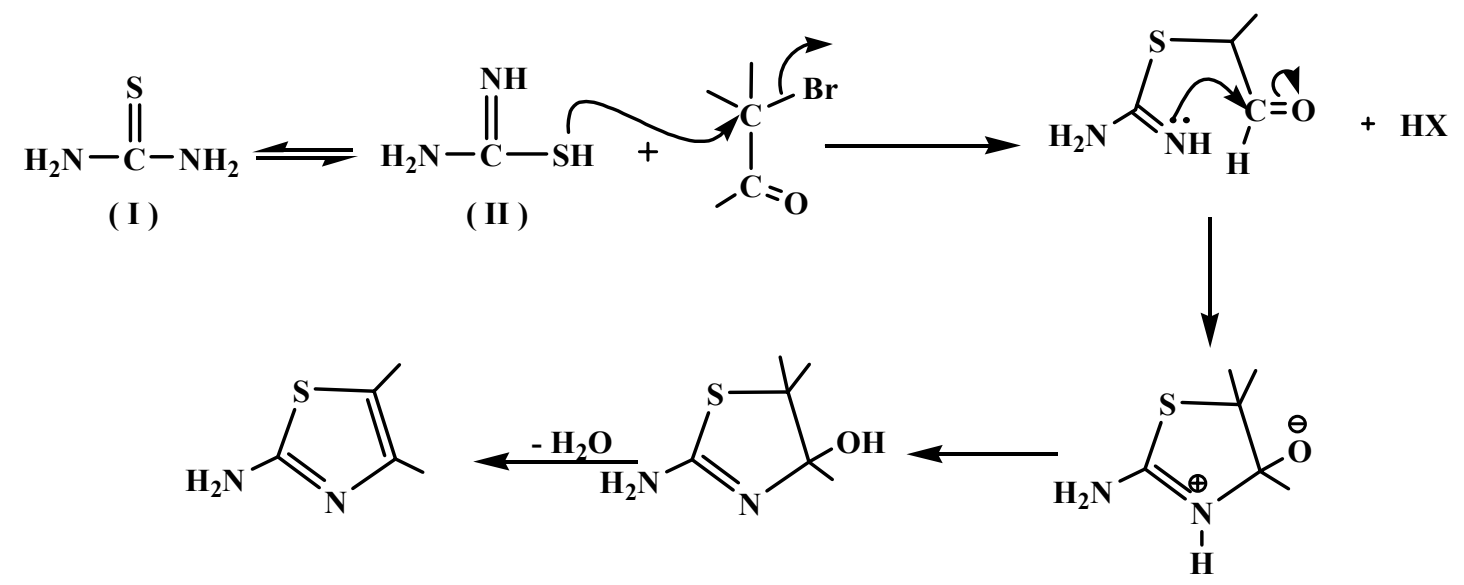

\section{Scheme (1)}

The structure of compounds $(5,6)$ was confirmed on the base of IR and UV spectra. The IR spectra showed the presence of absorption band at $\left(1624-1629 \mathrm{~cm}^{-1}\right)$ related to $(\mathrm{C}=\mathrm{N})$ bond stretching, $\left(1600-1604 \mathrm{~cm}^{-1}\right)$ related to $(\mathrm{C}=\mathrm{C})$ bond stretching and $\left(3240-3262 \mathrm{~cm}^{-1}\right)$ assigned to (NH) bonds stretching. While the UV spectra showed $\lambda_{\max }$ at $(254-256 \mathrm{~nm})$ related to $\left(\pi \rightarrow \pi^{*}\right)$ and $(293-300 \mathrm{~nm})$ related to $\left(\mathrm{n} \rightarrow \pi^{*}\right)$ transition (Finar, 1977).

The compounds $(7,8)$ were prepared by the condensation reaction of $\alpha$-bromo ketone $(3,4)$ with compound $(5)$ (scheme 3 ). This reaction proceeded through substitution-addition mechanism as shown in (scheme 2).

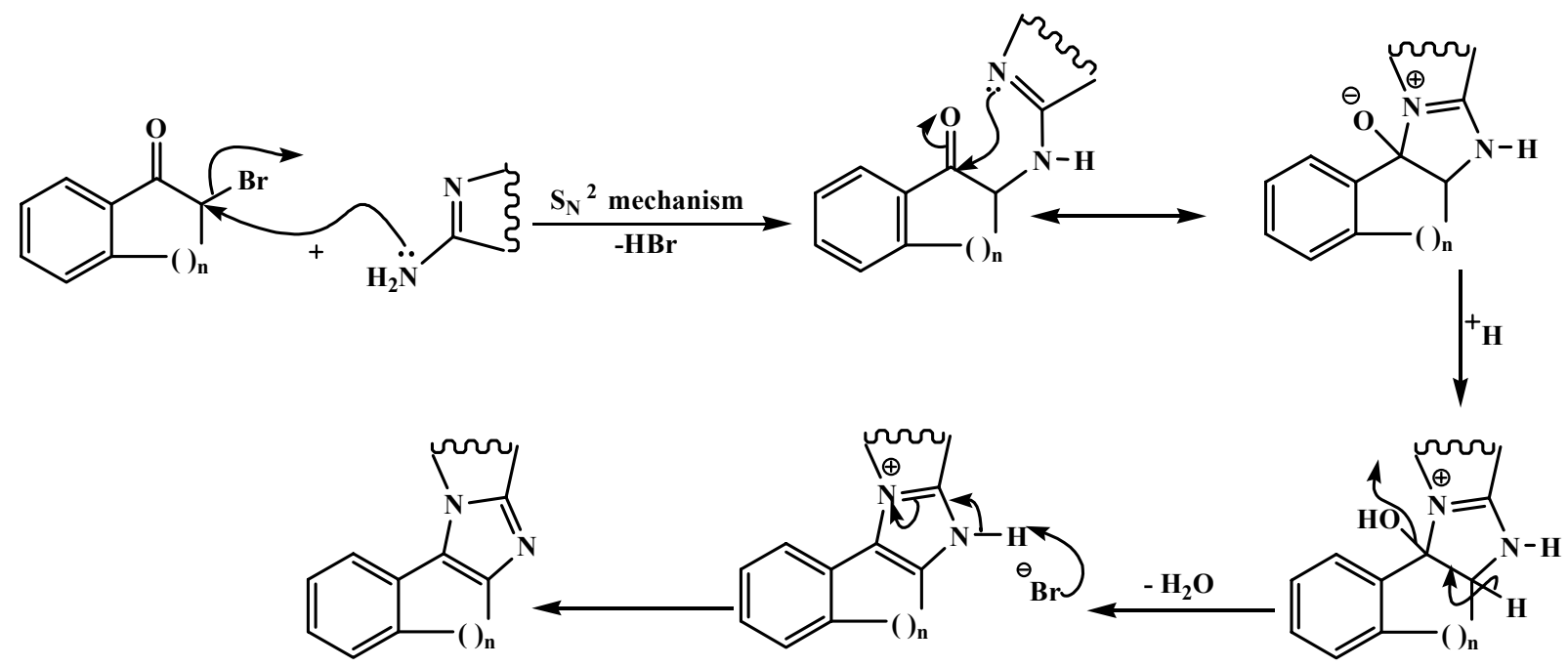

(6-13)

$[n=1,2]$

\section{Scheme (2)}

The IR spectral data of compounds $(7,8)$ showed absorption bands at $\left(646-648 \mathrm{~cm}^{-1}\right)$, $\left(1348-1388 \mathrm{~cm}^{-1}\right) ;\left(1561-1623 \mathrm{~cm}^{-1}\right)$ and $\left(1630-1687 \mathrm{~cm}^{-1}\right)$ which are related to bond stretching of $(\mathrm{C}-\mathrm{S}),(\mathrm{C}-\mathrm{N}),(\mathrm{C}=\mathrm{C})$ and $(\mathrm{C}=\mathrm{N})$ groups respectively (Nakanishi, 1962). The UV spectra of these compounds showed absorption band at $\lambda_{\max }(252-280 \mathrm{~nm})$ and $(316-336$ $\mathrm{nm})$ due to the $\left(\pi \rightarrow \pi^{*}\right)$ and $\left(\mathrm{n} \rightarrow \pi^{*}\right)$ transition and ring system (Parikh, 1974; Finar, 1977). 
$\alpha$-Bromo ketones $(3,4)$ was allowed to react with 2-amino-5-phenyl-1,3,4-thiadiazole (a) in alcoholic solution to afford the corresponding compounds $(9,10)$ (Dodson and King, 1945; King and Hlavacek, 1950) (scheme 2 and 3). The obtained products $(9,10)$ were identified by their IR data. There infrared spectra show the following bands (1336-1376 $\left.\mathrm{cm}^{-1}\right),\left(1030-1034 \mathrm{~cm}^{-1}\right),\left(1604-1631 \mathrm{~cm}^{-1}\right)$ and $\left(1630-1690 \mathrm{~cm}^{-1}\right)$ which related to $(\mathrm{C}-\mathrm{N})$, $(\mathrm{N}-\mathrm{N}),(\mathrm{C}=\mathrm{C})$ and $(\mathrm{C}=\mathrm{N})$ groups respectively (Phllips et al., 1998; Parikh,1974; Nakanishi, 1962). The UV spectra showed lower wave length in $\lambda_{\max }$ at $(238-248 \mathrm{~nm})$ and $(300-314$ $\mathrm{nm})$ due to the $\left(\pi \rightarrow \pi^{*}\right)$ and $\left(\mathrm{n} \rightarrow \pi^{*}\right)$ transition and steric effect (Finar, 1977; Katritzky and Rees, 1984).

Imidazo[2,3-b]1,3,4-tetrahydro triazole $(10,11)$ were prepared by condensation of $\alpha$ bromo ketone $(3,4)$ and 5-phenyl-1,3,4-triazole-2-thiol (b) in the presence of alcohole as yellow crystalline products, (scheme 2 and 3 ). The structure formula of $(11,12)$ were confirmed on the bases of their IR and UV spectra. The IR spectra showed the absorption band at (1029-1061 $\left.\mathrm{cm}^{-1}\right)$ for (N-N) bond stretching, (C-S) absorption band at $\left(649-683 \mathrm{~cm}^{-}\right.$ $\left.{ }^{1}\right),(\mathrm{C}-\mathrm{C})$ absorption band at $\left(1577-1623 \mathrm{~cm}^{-1}\right)$ and $(\mathrm{C}=\mathrm{N})$ absorption band at $(1630-1686$ $\mathrm{cm}^{-1}$ ), (Nakanishi, 1962; El-Rayyes and Al-Jawhary, 1986), while the UV spectra showed maximum absorption at $\lambda_{\max }(242-250 \mathrm{~nm})$ and $(302-308 \mathrm{~nm})$ due to the $\left(\pi \rightarrow \pi^{*}\right)$ and $\left(\mathrm{n} \rightarrow \pi^{*}\right)$ transition and also to the steric effect (Parikh, 1974) .

The final compounds $(13,14)$ synthesized from the reaction of corresponding 2-amine 5-phenyl-1,3,4-oxadiazole (c) with $\alpha$-bromo ketone $(3,4)$ (Wiley, 1945) (scheme 2 and 3). The IR spectra for these compounds showed absorption bands at $\left(1661-1682 \mathrm{~cm}^{-1}\right)$ assigned to $(\mathrm{C}=\mathrm{N})$ bond stretching, $\left(1596-1616 \mathrm{~cm}^{-1}\right)$ assigned to $(\mathrm{C}=\mathrm{C})$ bond stretching, $(1347-1386$ $\left.\mathrm{cm}^{-1}\right)$ for $(\mathrm{C}-\mathrm{N})$ bond stretching, sym. at $\left(1118-1172 \mathrm{~cm}^{-1}\right)$ and asym. at $\left(1213-1247 \mathrm{~cm}^{-1}\right)$ related to (C-O-C) bond stretching and $\left(1070-1084 \mathrm{~cm}^{-1}\right)$ related to $(\mathrm{N}-\mathrm{N})$ bond stretching. The UV spectra of compounds $(12,13)$ showed absorption band at $\lambda_{\max }(246-248 \mathrm{~nm})$ and $(304-316 \mathrm{~nm})$ related to the electronic transition $\left(\pi \rightarrow \pi^{*}\right)$ and $\left(\mathrm{n} \rightarrow \pi^{*}\right)$ (Finar,1977). 


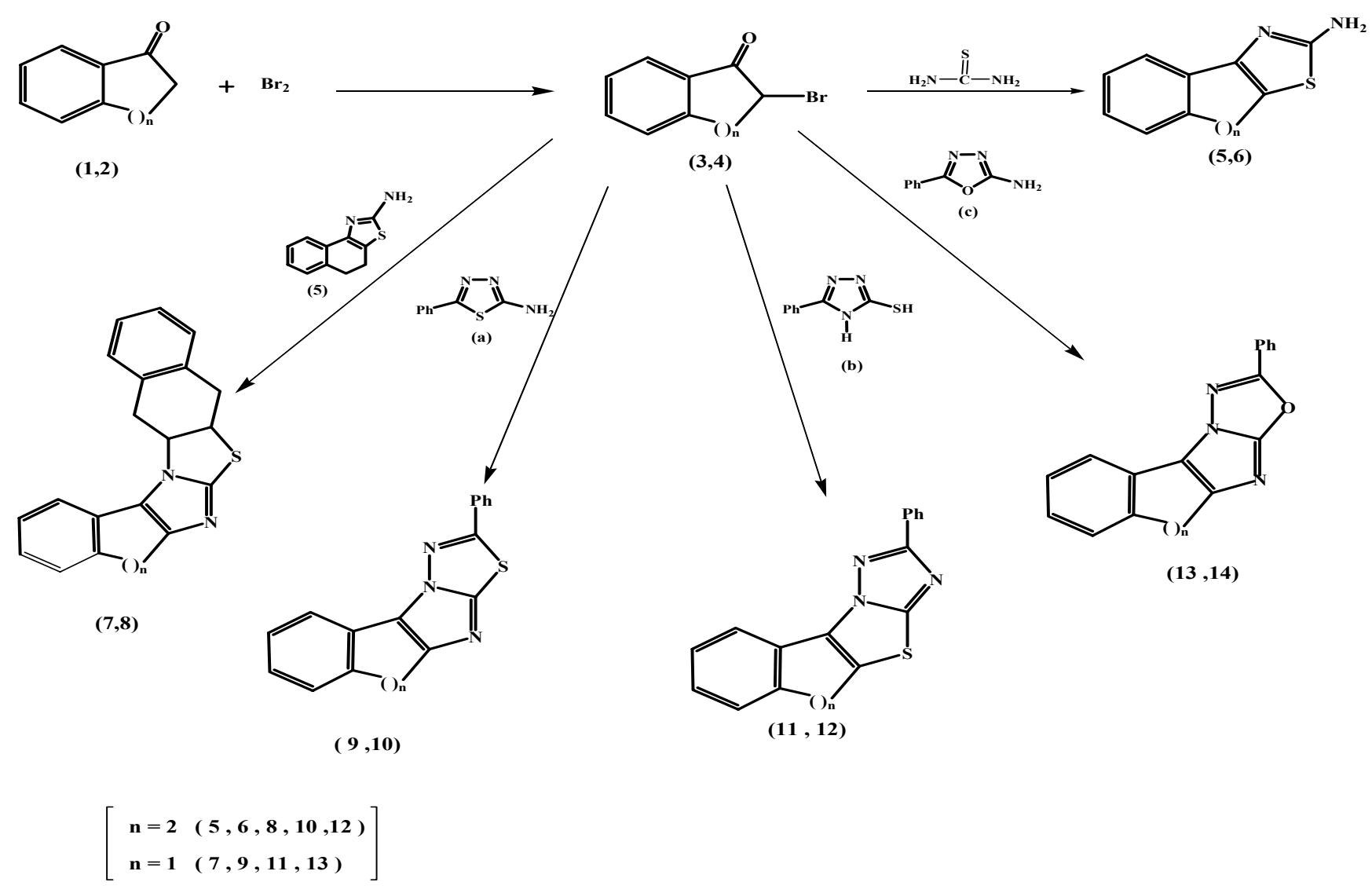

Scheme (3)

\section{REFERENCES}

Al-juboory, A. O. M. O. (2001). Synthesis of some new coumarine compounds and the study of their biological activity, M.Sc. thesis, Mosul University.

Arcus ,C. L.; Barrett, G. C. (1958). Heterocyclic analogues of fluorine : indeno (1 $\left.{ }^{-} 2^{-}-4: 5\right)-$ thiazoles from 2-bromo indan-1-one, J. Chem. Soc., 3, 2740.

Bakhite, E. A.; Mohammed, O. S.; Radwan, S. M. (2002).Synthesis and reactions of some new thieno [2,3-c]-pyridazine derivatives, Bull. Korean Chem. Soc., 23, 12, 1715.

Barger, G.; Dale, H. H. (1910). 4- $\beta$-Aminoethylglyoxaline ( $\beta$-imin-azolyl-ethylamine) and the other active principles of ergot, J. Chem. Soc., 97, 2592-2595.

Brown, R. F. C.; Eastwood, F. W.; Chaichit, N.; Gathahouse, B. M.; Pfeiffer, J. M.; Woodroffe, D. (1981). Methyleneketenes and methylen carbenes XVI the formation of diphenyl furan-2-ones and 3-phenyl phthalide as minor products of the pyrolysis of diphenyl propiolate, Aust. J. Chem., 34, 1467-1481.

Brunet, P.; Hornych, A.; Guyene, T. T.; Sioufi, A.; Turri, M.; Menard, J. (1995). Renal and endocrine effects of flosulide, after single and repeated administration to healthy volunteers, Eur. J. Chin. Pharmacol, 49, 193-201. 
Cazzulani, G. G. P.; Luca, C.; Nava, G.; Testa, R. (1983). Denzimol, a new anticonvulsant drug. II. general pharmacological activities, Arzneim-Forsch, 33, 1161-1168.

Christopher, G. L.; Wan, Z. K. (2008). Efficient phosphonium -mediated synthesis of 2amino-1,3,4-oxadiazoles, Org. Lett., 10(9), 1755-1758.

Dale, H. H.; Laidlaw, P. P. (1910). The physiological action of $\beta$-imidazolyl ethylamine, $J$. Physiol Land., 41, 318-344.

Dale, H. H.;Laidlaw, P. P. (1911). Further observation on the action of $\beta$-iminazolyl ethyl amine, J. Physiol. Lond., 43, 182-195.

Davood, A.; Alipour, E.; Shafiee, A. (2007). Efficient synthesis of imidazole derivatives : an important synthon for the preparation of biologically active compounds, Turk. $J$. Chem., 32, 389-395.

Demirbas, A.; Sahin, D.; Demirbas, N.; Karaoglu, S. A. (2008). Synthesis of some new 1,3,4-thiadiazole-2-yl-methyl-1,3,4-triazole derivatives and investigation of their anti-microbial activities, Eur. J. Med. Chem., 16, 1-2 .

Dodson, R. M.; King, L. C. (1945). The reaction of ketones with halogens and thiourea, J. Am. Chem. Soc., 67, 2242.

Edelsten, P. M. M.; Nielsen, V. F.; Scarpellini, A.; Skytte, S.; Slot, C. (1993). Formation and antimycotic effect of cyclodextrin inclusion complexes of enconazole and miconazole, Int. J. Pharm. (Amsterdam), 90, 247-254.

Eisa, A. Y. O. (2006). Synthesis of some five-membered heterocyclic derived from thymol expected biological activity, MSc thesis, Mosul University.

Eisa, M. A. A., (2000). Synthesis and study of some substituted biologically active oxadiazole, thiadiazole and triazole, MSc thesis, Mosul University.

Finar, I.L., (1977). "Organic Chemistry". Longman, Vol. 2, pp.17-18.

Furtado, D. D. M.; Minami, P.S. (1997). In vitro susceptibility tests of dermatophytes to grieoulvin and imidazole derivatives, Rev. Microbiol., 28, 110-115.

Gong, Y. X.; Yong, X. H. (2006). 1-(4-Bromo benzenoyl)-3-(5-trifluoromethyl-1,3,4thiadiazol) urea, Acta Cryst., E 62, 3193-3194.

Hadizadeh, F.; Vosooghi, R. (2008). Synthesis of $\alpha$-[5-(5-amino-1,3,4-thiazole-2-yl)-2imidazoly thio] acetic acids, J. Heterocyclic Chem., 45, 1-3.

Hetzheim, A.; Kerstan, C.; Weiher,B.,; Mogenstern, E. (1990). Verfahren zur synthesis neuer 1- substituierter -2-piperidino-4-aryl-imidazole mit anticonvulsiver wirkung, German Patent, 294, 940.

House, H. O.;Paragamian, V.; Rolland, S. R.; David; J. W. (1960). The synthesis of derivatives of 1-indanone and indenone, J. Am. Chem. Soc., 82, 1452-1457.

Husain, M. I.; Jamal ,M. R. (1987).Synthesis and pharmacological evaluation of N-[p-(3aryl-4-oxoquinazoline-2-yl-methyl amino) benzoyl]-B- arylthiosemicarbazides and 2-aryl amino-5-[p-(3-aryl-4-oxoquinazoline-2-yl-methyl amino) phenyl]1,3,4-thiadiazols/ oxadiazoles as oral hypoglycemic agents, Indian Journal Chemistry, 27B, 43-46.

Jasinski, M.; Mloston, G.; Mucha, P.; Linden, A.; Heimgartner, H. (2007). Synthesis of new bis- imidazole derivatives, Helvetica Chimica Acta, 90(9), 1765-1780.

Johnson, D. (1999). Process for the preparation of tetralone imines for the preparation of active pharmaceutical compounds, Eur. Patent, 30, 081, (vi), 1-73.

Katritzky, A.R. ; Rees C.W. (1984). "Comprhensive Heterocyclic Chemistry”. Progman, 
New York, Vol. 3, pp.594, 741, 760.

Keppler, B. K.; Rupp, W.; Juh,1, U. M.; Endres, H.; Niebl, R.; Balze, W. (1987). Synthesis, molecular structure, and tumor- inhibiting properties of imidazolium trans- bis (imidazole) tetrachlororuthenate (III) and its methyl substituted derivatives, Inorg. Chem., 26(26), 4366-4370.

King, L. C.; Hlavacek, R. J. (1950). The reaction of ketones with iodine and thiourea, J. Am. Chem. Soc., 72, 3722.

Koelsch, C.F. (1950). Bromonation of 3-Acetocoumarin, J. Am. Chem. Soc., 72, 29932995.

Labanauskas, L.; Brukštus, A.; Udrenaite, E.; Gaidelis, P.; Bučinskaite, V. (2003). Synthesis and anti-inflammatory activity of 2-(1H-benzo[d]imidazol-2-yl-sulfanyl)-and 2(1H-benzo[d]imidazol-2-yl-methyl sulfanyl)-1-(3,4-dialkyl oxyphenol)-1ethanone derivatives, chemija (vilnius), 14(1), 49-51.

Liverton, N. J.; Butcher, J. W.; Claiborne, C. F.; Claremon, D. A.; Libby, B. E., Nguyen, K.T.; Pitzenberger, S. M.; Selnick, H. G.; Smith, G. S.; Trbben, A.; Vacca, J. P.; Varga, S. L.; Agapwal, L.; Dancheck, K.; Forsyth, A. J.; Fletcher, D. S.; Frantz, B.; Hanlon, W. A.; Harper, G. F.; Hofsess, S. J.; Kostura, M.; Lin, J.; Luell, S.; O'neill, E. A.; Orevillo, C. J.; Pang, M.; Parsons, J.; Ronaldo, A.; Sahly, Y.; Visco, D. M.; Okeefe, S. J. (1999). Design and synthesis of potent selective, and orally bioavailable tetrasubstituted imidazole inhibitor of $\mathrm{p}^{38}$ mitogen-activated protein kinase, J. Med. Chem., 42(12), 2180-2190.

Magnus, N. A.; Diserood, W. D.; Nevill, C. R. J.; Wepsiec, J. P. (2006). Synthesis of imidazole based $\mathrm{p}^{38}$ MAP(mitogen-activated protein) kinase inhibitors under buffered conditions, Org. Process Res. Dev., 10(3), 556-560.

March, J. (1977). “Advanced Organic Chemistry”. 2nd Edn, McGraw-Hill international Book company, 41p.

Nakanishi, K. (1962). “Infrared Absorption Spectroscopy Practical”. Stanford Univercity, Nankodo Company Lmited, 38 p.

Nardi, D.; Tajana, A.; Leonardi, A.; Pennini, R.; Portioli, F.; Magistretti, M. J.; Subissi, A. (1981). Synthesis and anticonvulsant activity of N-(benzoylalkyl) imidazoles and N- (w-phenyl-w-hydroxy alkyl) imidazoles, J. Med. Chem., 24, 727-731.

Parikh, V.M. (1974). "Absorption Spectroscopy of Organic Molecules”. Edition Wesely Publishing Comp., Inc., pp. 246 - 251.

Phillips, C.; Jaime, R.; Marcel, J. (1998). "Organic Structure Analysis”. Oxfored University Press, Inc, pp.338-340.

Piatnitski, C. E. L.; Elokdah, H. M.; Butera J. (2008). Efficient one-pot synthesis of substituted 2-amino-1,3,4-oxadiazole, Tetrahedron Letters, 49(47), 6709-6711.

Riviera, D. F. L.; Coucuzza, C.; Bellotti, M. G. (1992). Antibacterial, antimycotic and trichomonicidal activity of a new nitro imidazole (Eu 11100), J. Chemother., 6, 342-346.

Robertson, D . W.; Krushinski, J. H.; Beedle, E. E.; Leander, J. D.; Wong, D. T.; Rathbun, R. C. (1986). Structure-activity relationships of (arylalkyl) imidazole anticonvulsants: comparison of the (fluorenylalkyl) imidazoles with nafimidone and dezimol, J., Med. Chem., 29, 1577-1586. 
Rossi, C. A. A.; Leonardi, A.; Testa, R.; Nardi D. (1989). Synthesis and anticonvulsant evaluation of 1,2-diphenylethane derivatives, Potential Metibolites of Denzimol, Farmaco (Lausanne), 44, 595-607.

Roth , H. J.; Fenner, H. (1994). Pharmazeutische chemec III arzneistoffe, Georg Thiem Verlag, Stuttgart., Germany.

Rutherford, K. G.; Stevens ,C. L. (1955). Enil ester of $\alpha$-halo ketones, J. Am. Chem. Soc., 77, 3278-3280.

Saxena, A.; Fedorko, J. M.; Vinayaka, C. R.; Medhekar, R.; Radic, Z.; Taylor, P.; Lockridge, O.; Bhupendra, P. (2004). Aromatic amino-acid residues at the active and peripheral anionic sites control the binding of E2020 (aricept ${ }^{\mathrm{R}}$ ) to chlorinesterase, Eur. J. Biochem., 270(22), 4447-4458.

Shieh, W. C.; McKenna, J. (2008). Process for the synthesis of 5-(methyl-1h-imidazol-1yl)-3-(trifluromethyl)-bezenamine, USPTO Patent Application, 20080188656.

Urbanik, E.; Zabielska-Matejuk, J.; Skrzypezak, A.; Pernak, J. (1998). Antifungal properties of new imidazolium chlorides against coniophora puteana coniophora puteana (schum. Fr) karst, trametes versicolor trametes versicolor (L. Fr.) pilat and chaetomium globosum chaetomium globosum (Kunze Fr.), Mater Org. (Berlin), 31, 247-263.

Werbrouck, S.P.O.; Debergh, P. C.(1996). Imidazole fungicides and paclobutrazo enhance cytokinin-induced adventitious shoot proliferation in araceae, J. Plant Growth Regul., 5, 81-85.

Werbrouck, S. P. O. P.; Redig, H. R.; Onckelen, V.; Debergh, P. C. (1996). Gibberellins play a role in the interaction between imidazole fungicides and cytokinins in araceae, J. Plant Growth Regul., 15, 87-93.

Wiley, R. H.; England, D. C.; Behr L. C. (1951). "Orgnic Reactions". John Willy and Sons, Inc, London, Sydney, vi, 367-409.

Yarovenko, V. N.; Lysenko, O. V.; Krayushkin, M. M. (1993). Synthesis of derivatives of 2- amino-1,3,4-oxadiazole-5-hydroxamic acid, J. Chem. Heterocycl. Compd., 29, 452- 454 . 